Cakrawala Dini: Jurnal Pendidikan Anak Usia Dini | p-ISSN 2087-1317 | e-ISSN 2621-8321 Vol. 12. No.2 November 202I | Hal 146-151

\title{
THE STRESS PROFILE OF EARLY CHILDHOOD EDUCATION TEACHERS DURING ONLINE LEARNING
}

\author{
Faqih Purnomosidi ${ }^{1}$ \\ ${ }^{1}$ Universitas Sahid Surakarta
}

\begin{abstract}
This study aims to determine the description of stress in Early Childhood Education (ECE) teachers during online learning. The approach in this study was qualitative with a phenomenological method. The number of informants in this study was seven informants. The informants were preschool teachers who make online learning. Data collection was obtained through interviews and observations. The results showed that the stress symptoms experienced by informants were in the form of memory impairment, decreased concentration, quickly excessive anxiety, loss of interest, inability to relax, and trouble sleeping. The source of stress for each informant was making online learning videos during the pandemic and the depletion of economic, social, and psychological resources.

Keywords: Stress, Online Learning, Kindergarten Teacher.
\end{abstract}

\begin{abstract}
Abstrak: Penelitian ini bertujuan untuk mengetahui gambaran stres pada guru Pendidikan Anak Usia Dini (PAUD) Semata Hati School selama pembelajaran dalam jaringan (daring). Pendekatan dalam penelitian ini adalah kualitatif dengan metode fenomenologi. Jumlah informan dakam penelitian ini adalah tujuh informan yaitu guru PAUD Semata Hati School yang membuat pembelajaran daring. Pengambilan data diperoleh melalui wawancara dan observasi. Hasil penelitian menunjukkan gejala stres yang dialami informan berupa gangguan daya ingat, konsentrasi menurun, mudah cemas berlebih, kehilangan minat, tidak mampu rileks dan mengalami gangguan tidur. Sumber stres setiap informan merupakan membuat video pembelajaran daring selama pandemi, serta penyusutan sumber daya ekonomi, sosial, dan psikologis.
\end{abstract}

Kata Kunci: Stres, Pembelajaran online, Guru PAUD

\footnotetext{
' Universitas Sahid Surakarta, Email: fagihpsychoum26国gmail.com
} 


\section{INTRODUCTION}

The Covid-19 pandemic has had many impacts on many sectors. One of which is the education sector. In order to reduce the spread of Covid-19, the government implemented a social distancing strategy, one of which was by closing schools. Another policy to meet the educational needs of children is to apply learning strategies at home and face-to-face learning with the application of strict protocols. The Ministry of Education and Culture of Indonesia has implemented several learning policies for children during the pandemic by prioritizing health and safety. The government's policy to fulfill children's education rights during the pandemic can be seen in two periods. First, the implementation of education during the pandemic. Second, the implementation of the teaching process for the new academic year 2020/2021. The second period also took place in a pandemic atmosphere and was colored by the discourse of implementing the new normal situation and developing the spread of Covid-19. The Minister of Education and Culture of Indonesia appealed to all academic units to postpone holding events that invite many participants or replace them with video conferences or other online communications. Especially for areas that have been affected by Covid-19, online learning from home is applied and is considered the same as attending school or college. With this circular, learning from home begins as a strategy to fulfill children's education rights during the pandemic, one of which is at the ECE level (Handrarini et al., 2020).

ECE is given before entering elementary school, which is when children are 3-6 years old. Some educational institutions that provide ECE services include Kindergartens, Child Care Centers (TPA), Playgroups, and others. ECE is one of the most affected places in the education sector because ECE provides learning about child growth and development for early childhood, which is very necessary to do offline learning, which can make teachers experience stress. The Ministry of Education and Culture of Indonesia has provided several guidelines for implementing learning in adapting new habits (Ministry of Education and Culture, 2020). However, the question that arises is that the procedure is only based on adapting physical habits. At the same time, from the psychological aspect, it is almost not touched at all, even though many things must be considered. Many psychological problems have arisen due to the Covid-19 outbreak (Agung, 2020; Cao et al., 2020). One of the most significant impacts associated with online learning is stress. Study shows that stress contributes 50 to 70 percent to the onset of most diseases such as cardiovascular disease, hypertension, cancer, skin diseases, infections, metabolic and hormonal diseases, etc. When a person experiences severe stress, he will show signs of fatigue, headaches, loss of appetite, forgetfulness, confusion, nervousness, loss of sexual desire,

Sarafino (1994) defines stress as a condition caused by the interaction between the individual and the environment, causing a perception of distance between the demands that come from situations that originate from a person's biological, psychological and social systems. Stress is internal and external pressure and other problematic conditions in life (internal and external pressure and other troublesome conditions). Sarafino (1990), individual responses to the stress they face include; anxiety; anger and aggression; apathy and depression; and cognitive impairment. Ardani (2007) defines stress as a depressed state both physically and psychologically. According to Richard (2010), stress is a process that assesses an event as something threatening, or harmful and the individual responds to the event at physiological, emotional, 
cognitive, and behavioral levels. Stressful events can be positive (e.g., planning a wedding) or negative (e.g., family death). Something is defined as a stressful event or not, depending on the response given by the individual to it.

ECE teachers must be able to make learning interesting for their students using playing games so that their students can be interested in what the teacher is saying to understand what their teacher is teaching. Then they can practice and do what their teacher has taught them.

Preliminary observations made by studies in March-September 2020 showed that many ECE teachers complained about online learning. We understand that early childhood prefers to learn offline rather than just watching videos or online, so that ECE teachers have to think about ways these students can accept what the ECE teacher teaches so that it triggers stress in some ECE teachers. Meanwhile, initial interviews conducted with ECE teachers showed that they always try to find new ideas or ideas on how to make learning exciting and easy to understand by their students.

Based on the explanation above, this study was conducted to know the description of the stress of ECE teachers of Semata Hati School in making online learning.

\section{METHODOLOGY}

This study used a qualitative approach with a phenomenological method. The focus of this study is to answer the question of how the stress picture of ECE teachers of Semata Hati School in making online learning during the Covid-19 pandemic. There were seven informants in this study. The selection of informants in this study was based on the following characteristics: (1) early childhood teachers alone; (2) stress due to online learning during the pandemic; (3) should conduct online learning. This qualitative study was conducted using a phenomenological approach. Data regarding the stress of ECE teachers of Semata Hati School in making online learning was disclosed using interviews.

Biological and psychological aspects such as: (1) feeling stressed with online learning activities during the Covid-19 pandemic so that they experience sleep disturbances; (2) feeling stressed with online learning activities during the Covid-19 pandemic so that they experience digestive disorders; (3) feeling stressed with online learning activities during the Covid-19 pandemic so that they experience excessive sweat production; (4) feeling stressed with online learning activities during the Covid-19 pandemic so that they experience memory problems; (5) feeling stressed with online learning activities during the Covid-19 pandemic so that concentration decreases; (6) feeling stressed with online learning activities during the Covid-19 pandemic so that they experience low self-esteem; (7) feeling stressed with online learning activities during the Covid-19 pandemic so that they experience mood disorders such as irritability; (8) feeling stressed with online learning activities during the Covid-19 pandemic so that they experience excessive anxiety; (9) feeling stressed with online learning activities during the Covid-19 pandemic so that they experience an inability to overcome problems; (10) feeling stressed with online learning activities during the Covid-19 pandemic so that they have difficulty in collaborating; (11) feeling stressed by online learning activities during the Covid-19 pandemic so that they have lost interest; (12) feeling stressed by online learning activities during the Covid-19 pandemic so that they experience an inability to relax. (8) feeling stressed with online learning activities during the Covid-19 pandemic so that they experience excessive anxiety; (9) feeling stressed with online learning activities during the Covid-19 pandemic so that they experience an inability to overcome problems; (10) feeling stressed with 
online learning activities during the Covid-19 pandemic so that they have difficulty in collaborating; (11) feeling stressed by online learning activities during the Covid-19 pandemic so that they have lost interest; (12) feeling stressed by online learning activities during the Covid-19 pandemic so that they experience an inability to relax. (8) feeling stressed with online learning activities during the Covid-19 pandemic so that they experience excessive anxiety; (9) feeling stressed with online learning activities during the Covid-19 pandemic so that they experience an inability to overcome problems; (10) feeling stressed with online learning activities during the Covid-19 pandemic so that they have difficulty in collaborating; (11) feeling stressed by online learning activities during the Covid-19 pandemic so that they have lost interest; (12) feeling stressed by online learning activities during the Covid-19 pandemic so that they experience an inability to relax. (10) feeling stressed with online learning activities during the Covid-19 pandemic so that they have difficulty in collaborating; (11) feeling stressed by online learning activities during the Covid-19 pandemic so that they have lost interest; (12) feeling stressed by online learning activities during the Covid-19 pandemic so that they experience an inability to relax. (10) feeling stressed with online learning activities during the Covid-19 pandemic so that they have difficulty in collaborating; (11) feeling stressed by online learning activities during the Covid-19 pandemic so that they have lost interest; (12) feeling stressed by online learning activities during the Covid-19 pandemic so that they experience an inability to relax.

\section{RESULT AND DISCUSSION}

The informants in the study were 7 (seven) people, experienced stress and financial impact. Informant I (TI) was 36 years old, Islam, Bachelor of ECE.
Informant II (T) was 25 years old, Islam, High School. Informant III (DV) is 22 years old, Islam, Bachelor of ECE. Informant IV (L) is 29 years old, Islam, high school. Informant V (S) 27 years old, Islam, Bachelor of ECE. Informant VI (US) 24 years old, Islam, Bachelor of ECE. Informant VII (S) 47 years old, Islam, Early Childhood Teacher Diploma. (see Table 1).

Table 1: Demographic of Informants

\begin{tabular}{|l|l|l|l|}
\hline Informants & Initial & Age & Education \\
\hline I & TI & 36 & Bachelor \\
\hline II & T & 25 & $\begin{array}{l}\text { High } \\
\text { School }\end{array}$ \\
\hline III & DV & 22 & Bachelor \\
\hline IV & L & 29 & $\begin{array}{l}\text { High } \\
\text { School }\end{array}$ \\
\hline V & S & 27 & Bachelor \\
\hline VI & US & 24 & Bachelor \\
\hline VII & S & 47 & Diploma \\
\hline
\end{tabular}

The four informants have different triggers behind the informant to become stressed during online learning. Informant I felt stressed during the delivery of materials and assessments; Informant II feels stressed when he is often in a bad mood and loses interest such as being lazy to chase deadlines; Informant III feels stressed at night because he thinks about learning which he fears is not in line with expectations; Informant IV feels stressed when they often re-take learning videos; Informant $\mathrm{V}$ felt stressed when making the video learning concentration decreased; Informant VI felt stressed when he wanted to start making learning videos feeling embarrassed; while Informant VII feels stressed when overthinking so that he experiences excessive anxiety.

\section{Discussion}

Sarafino and Smith (2012) say that the conditions caused by the interaction between individuals and the environment, giving rise to the perception of distance between demands, originate from situations originating in biological systems., psychological and social of a 
person. Stress arises as a result of demands that exceed the individual's ability to fulfill them.

Someone who can not meet the demands of needs will feel a condition of tension within. Tension that lasts a long time and there is no resolution, will develop into stress. Online learning is learning that uses the internet network with accessibility, connectivity, flexibility, and the ability to bring up various types of learning interactions. A study conducted by Zhang et al. (2004) shows that the use of the internet and multimedia technology can change the way knowledge is conveyed and can be an alternative to learning carried out in traditional classrooms. In Indonesia itself, online learning is rife at the emergence of the COVID-19 pandemic, so people still feel new, so they have to get used to it immediately.

The seven informants feel stressed when they are in their current condition, where learning for early childhood children should be offline learning because early childhood acceptance is limited and it is better if it is exemplified directly by the teacher. Plus, when they graduate, children have demands to read, write, and count (calistung) if they want to go to elementary school. That's when they feel as teachers they must have an important role in their learning during early childhood so that children can read, write and count after graduating from early childhood school, even though not all children grow the same way, coupled with the Covid-19 pandemic, which requires schooling from home in other words. Online learning.

The stress that accompanies the seven informants does not only come from within but also from family and society. Internal is related to feelings of current conditions, especially the impact of this online learning. This condition is a mismatch of expectations and demands received with the ability to carry it out, resulting in a discrepancy that creates pressure for the seven informants. The pressure received makes the informant need the help of others. The needs of this other person will make the individual feel loved and cared for, both the support received. The support felt Social support is from peers and the informant's family and students and guardians of students. This interaction enhances well-being, morale,

From the statements of the seven informants, it is known that each informant has a variety of responses to the stress they face. According to Sarafino (1990), individual responses to the stress they face include; anxiety, anger, and aggression; apathy and depression; and cognitive impairment. The anxiety felt by the seven informants during the pandemic was in the form of difficulties in terms of children not accepting and understanding what the teacher had conveyed in the learning video and financially to meet the needs of life itself. Then the response to anger and aggression shown by the seven informants was in the form of mood swings or anger for no apparent reason when under stress, but there were also informants who never showed an angry or aggressive response in the form of physical or verbal during online learning.

Furthermore, on the indicators of apathy and depression, it is known that seven informants admitted that they never showed a low self-esteem response during the online learning period when experiencing stress. While on the cognitive impairment indicator, the seven informants often found it challenging to concentrate when making learning videos by repeating take videos, often being distracted, because of boredom in making daily online learning and regarding family finances due to the impact of the pandemic, namely salary cuts, but it did not affect the performance of the seven informants. The results of data analysis also show that the stress of early childhood teachers at school starts from how they are required to carry out school 
programs from home resulting in the necessity to make online learning during the pandemic so that they become biologically or psychologically stressed. When you accept the conditions, you will see the steps taken to overcome stress in online learning.

\section{CONCLUSION}

ECE teachers who are the informants of this study have experienced stress since the beginning of the school program from home. They feel stressed in biology and psychology due to online learning even though they prefer to provide offline learning in general as before the pandemic. The informant found that it was not only the informant himself who experienced stress, but the informant could still solve the problems encountered during the online learning period. Adjustment amid online learning was considered the most significant obstacle faced by the informants. Informants who experience biological and psychological stress feel solidarity from friends in the same fate where the informant feels safe, gets support, and can provide support to others.

\section{REFERENCE}

Agung, I. M. (2020). Understanding the Covid-19 Pandemic from a Psychological Perspective

Ardani, T. A., Rahayu, I., Sholichatun, Yulia (2007). Clinical Psychology. Yogyakarta: Graha Ilmu.

Handrarini, et al. 2020. Online Learning as a Study From Home (SFH) Effort During the Covid 19 Pandemic. Journal of Office Administration Education (JPAP), 8(3), 496-503.

Cao. J. A., et al (2020). Post-Divorce Stress Coping: A Qualitative Study on Single Mothers. Journal of Psychology and Mental Health

Richard (2010). Coping with Stress In a Changing World. New York: McGraw-Hill
Sarafino, E. P., \& Smith, T. W. (2012). Health Psychology: Biopsychosocial Interactions (7th ed). New York; John Wiley \& Sons, Inc.

Zhang, D., Zhao, JL, Zhou, L., \& Nunamaker, JF (2004). Can elearning replace classroom learning? Communications of the ACM.

https://doi.org/10.1145/986213.98 6213.986216 